\title{
The Use of Digital Technologies in the Activities of Higher Educational Institutions is the Basis of the Industrial Future of the Territories
}

\author{
Irina Zhukovskaya ${ }^{1,2}$, Svetlana Begicheva ${ }^{3, *}$ \\ ${ }^{I}$ Tashkent State Economic University, Tashkent, Uzbekistan \\ ${ }^{2}$ Financial University under the Legal Office of the Russian Federation, Moscow, Russia \\ ${ }^{3}$ Ural State University of Economics, Yekaterinburg, Russia \\ ${ }^{*}$ Corresponding author.Email: begichevas@mail.ru
}

\begin{abstract}
This article shows that in the modern period, the development of the regional economy is unthinkable without the training of highly qualified personnel. Higher education institutions, which in the modern period are based on the use of digital technological solutions, are of great importance in the training of highly qualified specialists. In this article, the authors present the experience of using digital technologies at the Ural State Economic University and Tashkent State Economic University. In particular, it is noted that digital technological solutions make the educational process more adaptive, complex and interesting. The use of a virtual environment provides students with tremendous opportunities for self-development and research activities. In addition, innovative technologies help students to participate in the scientific development of start-up projects together with students from other universities and practitioners. The purpose of this article is to study the main directions of modernization of the activities of higher educational institutions based on the optimal use of digital technologies to improve the quality of education and management processes in universities in order to prepare highly qualified specialists for industries and spheres of the economy and the qualitative development of the country's regions in the context of the digital transformation of the global economic system.
\end{abstract}

Keywords: sustainable development of territories, higher education, digital technologies, management, teaching methods, innovative teaching technologies, highly qualified specialists, the industrial future of the territories.

\section{INTRODUCTION}

The formation of the digital economy on a global scale has an impact on the development of all aspects of society. All spheres of society are being transformed under the influence of digital technological solutions. Digital technologies have a huge impact on the sustainable development of regions. Which, in turn, is impossible without highly qualified specialists.

The experience of developed countries such as the USA, Japan, Canada, South Korea, Austria, Denmark, Great Britain, Germany, Israel, Norway, etc. shows that digital technologies not only have a significant impact on the learning process of students in higher educational institutions, but also serve the key to the successful implementation of socio-economic development programs that contribute to the growth of the well-being of the population and the country's competitiveness in the world economic market.

Practice urges that the digital environment contributes to the globalization of science and education, which is the key to the effective development of regions of different countries.

In addition, the theory of regional economics shows that regional development is a complex and complex process that requires a multidimensional approach. And in this aspect, it is necessary to take into account the factors of regional development, which include: the strategic location of the region, regional policy, the availability of natural resources, the availability and quality of human resources, etc. The qualifications of personnel operating at regional enterprises and organizations entirely depend on the quality of education 
of specialists with higher education. In this regard, modern universities play a leading role.

Despite the fact that each university is unique in the implementation of modern digital technologies, they all have one common goal - the release of highly qualified specialists capable of making competent and optimal decisions for the effective and sustainable development of regions.

This article examines the main trends in the use of digital technologies in the activities of the Ural State Economic University and the Tashkent State Economic University in order to train economists who can carry out their activities at economic facilities in various regions of the country, contributing to their sustainable development.

In addition, the authors of the article proved that digital programs for the development of regions should be aimed at maintaining the global competitiveness of regions by providing the most developed sectors with digital technologies and highly qualified personnel capable of working in a digital environment.

\section{MATERIALS AND METHODS}

In the process of writing this article, the basic provisions of the scientific methodology for studying phenomena and processes, methods of system and statistical analysis, decomposition and scientific generalization, monographic research, and work with Internet sources were used.

\section{RESULTS AND DISCUSSION}

\subsection{Analysis of Literary Source}

The process of digitalization of the economic system could not but affect the higher education system. Numerous works of scientists from all over the world are devoted to this topic. For example, the works of such foreign scientists as R. Barro, D. Weil, J. Kendrick and others reflect the conceptual foundations of the relationship between education and economic growth based on the use of innovative technologies.

The theory of economics of modern education has been studied in the works of scientists from far and near abroad. These include scientists such as B.A. Burnyashov [1], Allison DeeAnn [2], Owusu Boateng R., A. Amankwaa [3], A.A. Auzan, G. I. Abdrakhmanova, K. O. Vishnevsky, L. M. Gokhberg [4], J. M. Van Rienen, S.Yu. Glazyev [5], M. Dhonson [6], A.V. Keshelava [7], O. Kivinen, B. Clark, A. Arutyunova, I.E. Zolin [8], S.L. Kostanyan, A. Maddison, Novoseltseva G.B., N.V. Rasskazova, T.N. Savina [9], A.S. Slavyanov, S.S. Feshina [10], K. Arrow and others.
A wide range of articles is devoted to the issues of introducing digital technologies directly into the educational process of higher educational institutions. This range of works includes works by such authors as I.Z. Geliskhanov, T.N. Yudina, A.V. Babkin [11], T.N. Savina [12].

Particularly noteworthy are the works of scientists of the Ural scientific school, such as E.G. Animitsa, N.Yu. Vlasova [13], E.B. Dvoryadkina [14], D.M. Nazarov, S.V. Begicheva [15], in which the topical issues of the use of digital technologies in the activities of the regions are considered, and the main directions of training specialists for the sustainable development of regions are noted.

Modern scientists of Uzbekistan - R.Kh. Alimov [16], B.A. Begalov [17], S.S. Gulyamov [18], R.A. Dadabaeva, I.E. Zhukovskaya [19], A.T. Shermukhamedov [20] also comprehensively investigate the problem of using digital technologies in various sectors and spheres of the national economy of the Republic of Uzbekistan, including the country's higher economic education. In the works of Uzbek scientists, it is noted that in the conditions of the development of the digital economy, a close relationship is needed between science, education, enterprises and organizations of various industries and spheres of the national economy. In addition, the authors have proven that the development of the regions of Uzbekistan in the modern period is based on innovative technologies in various areas of the regional economy and the fundamental knowledge of graduates of higher educational institutions.

A large range of works by modern scientists is devoted to the implementation of artificial intelligence in the activities of higher educational institutions [20, 21]. Studies show that in the classical sense, artificial intelligence is defined by scientists as a certain property of intelligent systems to perform creative functions inherent in humans. The technology of creating intelligent machines using special software is based on the application of this property.

For example, the authors of the research "Artificial Intelligence in Higher Education. Current Uses and Future Applications "(Learning House, 2018) state that artificial intelligence systems in universities are most often used in the following aspects:

- identification and testing of applicants for admission to the university;

- acceleration of learning;

- complex tasks in the process of teaching students at the university;

- optimization and comprehensive adaptation of educational programs in the areas of study at the university. 
Scientists emphasize that chat bots are applicable when recruiting students to a university. For example, a chatbot such as AdmitHub, equipped with AI, is very effective in advising American applicants on admission and admission issues, as well as on the terms of tuition fees existing at the university.

In addition, foreign researchers note that artificial intelligence has gained its recognition when using various simulators. As an example, they cite the ShadowHealth medical system, which simulates the symptoms of various diseases, teaching future diagnostic doctors.

The digital platform M-Write teaches users the rules of academic writing and allows them to evaluate the knowledge gained by students in the course of their studies. In addition, foreign scientists note that many foreign universities use a machine tutor in the MATHiaU project, which helps students learn the basics of mathematics. According to foreign scientists, the development of EdTech start-ups of universities, or software products, the development of which was carried out by scientists in cooperation with students and practitioners in the field of artificial intelligence systems, is a great success in the field of application of artificial intelligence systems in higher education.

But, despite all the positive and multidimensional properties of artificial intelligence systems, scientists note that artificial intelligence, nevertheless, can never completely replace human labor. Because such human qualities as intuition, creative thinking, critical judgment, cognitive flexibility, compassion, benevolence, no technical and technological innovations can reproduce.

Analysis of the views of foreign and domestic scientists in the field of digital technologies application in higher education revealed the following provisions: the publications under consideration all reflect the global trends in the implementation of digital technologies in the educational and management process of universities; all authors note the importance of digitalization of the basic directions of the university's activities, and also pay close attention to teaching the teaching staff modern digital solutions.

In addition, an analysis of literary sources has shown that in the modern period higher educational institutions are increasingly using such components of digital education as operational communication systems, digital platforms, file digital archives, computer-training programs, actively use digital technological solutions in their activities, conducting webinars, online contests, conferences, etc.

Despite a solid number of projects and implemented developments on the use of digital technologies in the activities of higher scientific institutions, to date, a universal solution that allows you to fulfill all the tasks of optimizing the activities of a university through the use of digital technologies has not yet been developed. In this regard, the relevance of this article is beyond doubt.

\subsection{Digital Technologies are the Basis for Training Highly Qualified Specialists for Sustainable Development of Territories}

In the modern period of development of the world economy, digital technologies are firmly included in all educational institutions, contributing to the improvement of management processes and improving the quality of training.

Practice shows that digital technologies such as big data, blockchain, artificial intelligence, the Internet of Things, robotization, 3D modeling are today an effective tool for transferring knowledge and skills to students, serve as the basis for building a new educational environment, and a reliable assistant in improving the qualifications of faculty composition.

Speaking about the use of digital technologies in universities, it should be noted that along with positive trends in their implementation, such as innovation, accessibility, mobility, simplicity, uniqueness, usefulness, reduced time costs, reliability and simplification of thought processes, there are also difficulties. For example, the technical and technological training of universities, the availability of special software systems, resource consumption, special training of the teaching staff.

Techno-cities, techno-parks and IT ecosystems play an important role in the development of regions and the training of highly qualified specialists in the modern period.

Technoparks in Moscow, Samara, Sverdlovsk, Nizhny Novgorod, Penza and Ulyanovsk regions, as well as the Republics of Mordovia, Tatarstan and Bashkortostan and the Perm Territory have demonstrated the most efficient operation in Russia. According to the data of the Association of Clusters and Technoparks of Russia, according to the results of the VI National Rating of Technoparks of Russia, currently 179 technoparks function in Russia in 55 regions, including 65 industrial parks, 50 of them successfully operated in 2020, 15 were in the process of creation.

In turn, in the Republic of Uzbekistan, in order to solve problematic issues in the field of digital technologies and for the development of the IT ecosystem in the country, on January 10, 2019, a resolution of the Cabinet of Ministers of the Republic of Uzbekistan No. 17 "On measures to create a technological park of software products and information technologies" was adopted. Solving the tasks set in this document made it possible to build the so-called vertical 
of education and implement projects in the field of digital technologies through the integration of scientific and educational organizations with IT companies.

Speaking about the development of digital infrastructure in Uzbekistan in the field of higher education, it should be noted that a national megaproject, One Million Uzber Coders, has been implemented in the republic for more than a year. This project is aimed at training broad layers of education (especially young people) in IT specialties in demand at the present time using a specialized online portal. Anyone can undergo training and receive a certificate in the chosen IT direction, and then apply their knowledge in practice in the sectors and spheres of the national economy. The following results indicate the effectiveness of the implementation of the megaproject - One Million Uzber Coders.

According to the Ministry for the Development of Information Technologies and Communications of the Republic of Uzbekistan, 85 thousand people were registered on the uzbekcoders.uz platform during the year of the One Million Uzber Coders project.

These events are aimed at training competitive IT specialists, developing the IT ecosystem, developing and implementing start-up projects based on solving modern problems with the help of innovative developments that contribute to improving the quality of life of the country's population.

\subsection{Experience in Using Digital Solutions in the Activities of Economic Universities in Russia and Uzbekistan}

The Ural State Economic University and the Tashkent State Economic University are the forges of highly qualified economic personnel for the economies of Russia and Uzbekistan.

In the modern period, the teams of universities are working to achieve the highest results in educational, educational, scientific and international activities in order to occupy high positions in national and international rankings. Organizations such as Quacquarelli Symonds World University Rankings, Times Higher Education or Academic Ranking of World Universities.

Practice shows that a whole range of digital technologies is used in the activities of universities, ranging from the technology of using small informatization means to digital platforms.

The teaching staff of universities, when conducting classroom classes, professional seminars and other types of educational and scientific activities, effectively uses the technologies of joint experimental research of a teacher and student, multimedia technologies, Panoramic images technology, electronic content, 3D modeling using special software and hardware.
Both the Ural State Economic University and the Tashkent State Economic University have unique computer rooms connected to the virtual library server, which allows students, young scientists and faculty to carry out both preparation for classes and conduct scientific research on the most diverse subject.

The functioning of modern universities is unthinkable without digital platforms that allow faculty to develop various web-based courses. The main elements of these courses are text and graphic pages, all kinds of interactive tasks, e-mail newsletters, glossaries, dictionaries, links to literary sources, etc.

The digital platform allows not only a dialogue between the teacher and students on all components of the educational process, but also serves as a reliable assistant to the university leadership in monitoring the quality of the educational process, as well as during international conferences. An illustrative example of this is the holding of annual joint events between USUE and TSUE as part of a joint educational program.

More and more, when organizing the educational process in universities, the so-called VR technology is used - virtual reality technology. This technology allows you to generate images, that is, to represent a particular process in a three-dimensional image or sound iPhone, etc.

Speaking about the use of digital technologies, it is necessary to pay attention to blockchain technology, which can be used, for example, for student portfolios, document storage, exam papers, etc.

Digital technologies in the activities of universities contribute to the quality of training highly qualified specialists for the balanced and sustainable development of regions.

In addition, with the development of the material and technical base of the university, it becomes possible to use machine learning technologies, robotics, and artificial intelligence.

In addition, the development of digital technologies requires the teaching staff to constantly improve their qualifications in the use of advanced innovative technologies.

\section{CONCLUSION}

Experience shows that in the modern period, digital technological solutions are increasingly used in the activities of universities, which make it possible to make the transition to personalized learning, which is necessary to achieve the highest results of educational activities.

Digital technologies effectively influence the development of the digital infrastructure of universities. This aspect implies the development of communication 
channels, the acquisition of new devices for use in the educational process of digital teaching materials.

This article proves that the formation of a digital economy contributes to the development of the digital infrastructure of the university, an increase in the level of digital competence of all participants in the educational process at the university, which in turn serves as a guarantee of the training of highly qualified specialists for various industries and spheres of the national economy and, as a consequence, the growth of the country's competitiveness in the world economic market.

\section{REFERENCES}

[1] B.A. Burnyashov, Personalization as a global trend of e-learning in institutions of higher education. In: Modern problems of science and education, 1 (2017) p. $90 . \quad$ URL: https://elibrary.ru/item.asp?id=28401246

[2] A. DeeAnn, Chatbots in the Library: is it time?? Faculty Publications, UNL Libraries, p. 280 (2011). https://digitalcommons.unl.edu/libraryscience/280

[3] R. Owusu Boateng, A. Amankwaa, The Impact of Social Media on Student Academic Life in Higher Education. In: Global journal of human-social science: G Linguistics \& Education, 16(4) (2016) pp. 1-7.

[4] G. I. Abdrakhmanova, K. O. Vishnevsky, L. M. Gokhberg, What is the digital economy? In: Trends, competencies, measurement: reports. to XX Apr. international scientific. conf. on the problems of economic and social development, p. 82 (2019).

[5] S. Yu. Glazyev, Information and digital revolution. In: Eurasian integration: economics, law, politics, 1(23) (2018) pp. 70-83

[6] M. Dhonson, Personalization Is the Key to Transforming Education. In: National Review (2018).

https://www.nationalreview.com/2018/04/educatio n-technology-personalized-learning-better-results

[7] A.V. Keshelava, Digital tools of the digital economy: basic questions and definitions. http://integral-russia.ru/2019/09/10/tsifrovyeinstrumenty-tsifrovoj-ekonomiki-bazovye-voprosyi-opredeleniya/

[8] I.E. Zolin, The role of the digital economy in the development of the lifelong education system. In: Logos et Praxis, 18(1) (2019) pp. 41-51.

[9] T.N. Savina, Digital Economy as a New Development Paradigm: Challenges, Opportunities and Prospects. In: Finance and Credit, 3(771) (2018).
[10] A.S. Slavyanov, S.S. Feshina, Technologies of artificial intelligence in education as a factor in improving the quality of human capital. In: Economy and business: theory and practice, 7 (2019) pp. 156-159.

[11] I.Z. Geliskhanov, T.N. Yudina, A.V. Babkin, Digital platforms in the economy: essence, models, development trends. In: Scientific and technical statements of SPbSPU. Economic sciences, 11(6) (2018) pp. 22-36.

[12] T.N. Savina, Digital Economy as a New Development Paradigm: Challenges, Opportunities and Prospects. In: Finance and Credit, 3(771) (2018).

[13] E.G. Animica, N.YU. Vlasova, Territorial planning of the sub "ect of the Russian Federation, taking into account the development of urban agglomerations Modern trends in spatial development and priorities of social geography: materials of the International scientific. conf. of the 9th Annual Scientific Assembly of the Association of Russian Geographers and Social Scientists, pp. 10-14 (2018).

[14] E.B. Dvoryadkina, D.M. Prostova Nekommercheskie organizacii $\mathrm{v}$ regional'noj ekonomike: teoreticheskij podhod $\mathrm{k}$ issledovaniyu . In: Journal of New Economy, 20(4) (2019) pp. $47-$ 69. DOI: https://doi.org/10.29141/2073-1019-201920-4-3.

[15] I. Zhukovskaya, S. Begicheva, D. Nazarov, Innovative approach to higher education management as an important factor of sustainable economic development. In: E3S Web of Conferences, $09018 . \quad$ DOI: https://doi.org/10.1051/e3sconf/202020809018.

[16] R.Kh. Alimov, U.T. Hayitmatov, Prospects for the development of the digital economy in Uzbekistan . In: Collection of articles and abstracts of the Republican scientific-practical conference " Digital economies: modeling of economic development trends and prospects for the use of modern information and communication technologies ", pp. 12-20 (2019).

[17] B.A. Begalov, O.T. Mamadaliev, Reforms in the field of statistics of the Republic of Uzbekistan: results and development prospects. In: Statistics and Economics, 18(1) (2021) pp. 4-13. DOI: https://doi.org/10.21686/2500-3925-2021-1-4-13.

[18] S.S.Gulyamov, Digital economy: ten new technologies. In: Collection of scientific articles of the Republican scientific and practical conference on December 2, 2019 on the topic: "Digital economy: modeling trends in economic development and prospects for the use of modern 
information and communication technologies.", pp. 169-175 (2019).

[19] I.E. Zhukovskaya, The main directions of improving the methodology for the application of advanced information and communication technologies in the statistical activities of the Republic of Uzbekistan in the context of the formation of the digital economy. In: Statistics and Economics, 17(5) (2020) pp. 6880. DOI: https://doi.org/10.21686/2500-3925-20205-68-80.

[20] A.T. Shermukhamedov, Innovative development of the economy of Uzbekistan: intellectual potential. In: International scientific and practical conference "Data mining and digital economy" in Pyatigorsk (2018).

[21] R.A. Amirov, Strategy for the development of higher education in Russia. In: Bulletin of NGIEI, 8 (99) (2019) pp. 105-117.

[22] E.Yu. Esionova, Artificial Intelligence as an Alternative Resource for Learning a Foreign Language. In: Humanities and Social Sciences, 3 (2019) pp. 155-166. 